\title{
MOTOBOYS EM SÃO PAULO: GESTÃO DA VIDA NOS CIRCUITOS DA CIRCULAÇÃO NO ESPAÇO
}

\author{
RICARDO BARBOSA SILVA \\ Universidade de São Paulo
}

\section{Introdução}

Os motoboys que aparecem na paisagem urbana da cidade de São Paulo como um fenômeno muito recente, são caracterizados como uma multiplicidade confusa, embaralhada, que avança em disparada nas ruas e avenidas da cidade desestabilizando e, muitas vezes, pondo em xeque todo um diagrama de leis, de normas e de regras que visam a gerir os problemas no trânsito, tanto controlando possíveis acidentes, quanto majorando a intensidade de fluxos de mercadorias, de pessoas e informações.

É assim que a constituição cada vez mais exponencial do crescimento dessa atividade profissional, mais do que traduzir uma simples explosão de uma nova e pujante categoria de trabalhadores urbanos, a partir da natureza e da dinâmica permite deslindar os mecanismos de exercício das instâncias de poder na gestão da vida nos circuitos da circulação no espaço, intervindo nesta categoria como objeto e alvo do poder, normatizando suas condutas e comportamentos no espaço urbano da cidade de São Paulo.

Isso porque a atividade profissional dos motoboys aparece pondo mais combustão na situação conflituosa do trânsito da cidade, pois em uma espécie de via-crucis, eles disparam em altas velocidades, acelerando, explodindo os motores, apertando suas buzinas em um ritmo quase que intermitente, ziguezagueando entre um carro e outro, nos chamados corredores ${ }^{1}$.

É no trânsito, entre insultos e gentilezas, entre agressões físicas e morais, entre um acidente e outro, entre um retrovisor que cai e uma porta

${ }^{1}$ Espaço entre um veículo e outro nas ruas e avenidas da cidade de São Paulo. 
que amassa que eles aceleram forte, pois, antes de tudo, a entrega precisa chegar ao seu destino no tempo previsto e no local combinado. São eles, os chamados cachorros loucos ${ }^{2}$, que expõem vivos um dos problemas mais urgentes a serem geridos no espaço urbano no trânsito da cidade de São Paulo.

E, é nessa relação tênue, onde as questões se embaralham entre as exigências do tempo e os constrangimentos do espaço, entre a expectativa e a satisfação das entregas, entre o imprescindível e o estigmatizado, entre a luta pela vida e o desalento da morte, que a atividade profissional dos motoboys se liga a um novo diagrama de práticas socioespaciais na cidade de São Paulo na transição do século XX para o XXI.

Neste sentido, a abordagem deste artigo visa a compreender a natureza da atividade dos motoboys como reveladora de parte das transformações socioespaciais na cidade paulistana, como produto e necessidade de um contexto histórico de fin de siècle, na transição do século XX para o XXI, encarnando dois polos de um mesmo problema, a partir da nova condição da cidade e do mundo do trabalho. E, justamente, por encarnar essa condição contraditória, essa atividade profissional revelase como um ângulo privilegiado a fim de problematizar a gestão da vida nos circuitos da circulação no espaço urbano de São Paulo, como forma de normatizar e controlar esses trabalhadores - vistos como massas desordenadas no trânsito -, tornando-os úteis, dóceis e lucrativos.

\section{Na Garupa dos Motoboys: Características e Condições de Trabalho}

A categoria profissional que usualmente é chamada de motoboys recebe diversas denominações da sociedade. Algumas delas buscam caracterizá-los, outras estigmatizá-los. Alguns os chamam de motociclistas simplesmente, outros de motociclistas profissionais. O poder público, no caso a Prefeitura de São Paulo, denomina-os de motofretistas e, outros tantos, maldosamente, de cachorros loucos.

Neste artigo, a denominação usada será a de motoboys, pois não é sua intenção buscar uma melhor definição etimológica para esta categoria

\footnotetext{
2 Maneira pejorativa de denominar muitos motoboys, principalmente, aqueles que primam pela imperícia nas ruas e avenidas de São Paulo.
} 
profissional. Sabe-se que o termo motoboy ${ }^{3}$, em si, carrega algumas imprecauções no que se refere à caracterização dessa atividade ${ }^{4}$, porém diante da força que o termo carrega - tanto positivamente quanto negativamente - , o mesmo servirá para melhor ilustrar a problemática dessa classe trabalhadora.

De uma forma geral é uma atividade relativamente recente na dinâmica urbana de São Paulo. Conforme Gilvando Oliveira nos relata:

A ocupação surgiu no Brasil, no início da década de 80, mais precisamente no ano de 1984. O primeiro empresário de serviços de moto-entrega de que se tem notícia foi Arturo Filosof, um argentino que, em 1984, trouxe a idéia de Buenos Aires para São Paulo, onde fundou a Diskboy. Sua empresa levou alguns meses para receber a primeira encomenda, mas em 1985 já era amplamente conhecida na cidade, sendo noticiada em vários jornais e revistas nacionais (2003: 38).

Neste princípio, "A Diskboy" era a proprietária da frota de motos, todavia não demorou muito para ela se tornar destaque na relação das empresas que mais cometeram infrações no trânsito:
com 119 metros de multas [...] Essas infrações levaram a empresa a vender sua frota de 80 motos e contratar motociclista com moto própria, para se livrar das multas e por entender que o motoboy proprietário de seu veículo devia tornar-se mais responsável no trabalho (Ibid.:38).

Atualmente, a maioria dos motoboys é proprietária de suas motocicletas. Para eles possuir uma motocicleta tornou-se um ponto de partida para a inserção nesta atividade profissional, funcionando como um dos atributos de seleção nas empresas. Foi assim que nos contou o motoboy Marcos, de 27 anos: "tem que ter moto, se não, não trabalha. Geralmente a maioria tem sua moto própria. Se não tiver moto a empresa

\footnotetext{
${ }^{3}$ A palavra motoboy, de origem inglesa, é um neologismo composto pela junção de duas palavras (motorcycle $=$ moto e boy $=$ garoto).

${ }^{4}$ Já que, além de não dar conta de muitas mulheres que vêm ocupando postos nessa atividade, sabe-se que essa profissão não é com exclusividade vinculada a jovens, uma vez que uma parcela considerável dessa categoria vincula-se à idade adulta.
} 
nem aceita. A empresa não quer ter vínculo nenhum". Além disso, o motoboy Carlos Eduardo, de 26 anos, nos relatou que "a maioria dos motoboys, uns $80 \%$, tem que bancar as despesas da moto", despesas essas que variam desde a manutenção, reparos e troca de peças da motocicleta, o combustível para abastecê-la, o óleo para o motor aos equipamentos de seguranças necessários e obrigatórios.

Mesmo sem uma evidência mais rigorosa do ponto de vista empírico que a comprove, a quantidade e o crescimento dessa atividade profissional dos motoboys ${ }^{5}$ é inegavelmente um fenômeno urbano visto a olhos nus nas ruas e avenidas de São Paulo e das grandes cidades do Brasil. Em entrevista a nós concedida, Gilberto Almeida dos Santos, "Gil", Presidente do Sindicato dos Mensageiros Motociclistas, Ciclistas e Moto-Taxistas do Estado de São Paulo, disse-nos assim sobre a questão: "creio que entre 200 e 250 mil só na cidade de São Paulo".

Sobre a atividade dos motoboys que se realiza particularmente na cidade de São Paulo, um estudo publicado pela CET (Companhia de Engenharia de Tráfego), em 2002, nos dá algumas indicações. Neste estudo, foram entrevistados 999 motociclistas na cidade de São Paulo e desses cerca de $67 \%$ eram motoboys e $33 \%$ deles eram motociclistas (usavam a moto como meio de transporte ou lazer). Outro estudo publicado pela CET, em 2003, mostra que dos 1.141 motociclistas entrevistados, $62 \%$ eram motoboys e $38 \%$ eram motociclistas.

Esse fenômeno urbano, mais do que produto da espontaneidade, reproduz-se como produto e necessidade de um processo contraditório de transformações socioespaciais na cidade de São Paulo, baseado na transição para um regime de acumulação flexível que, à primeira vista, parece vincular-se estritamente aos escopos da economia, entretanto, espraia-se na emergência de novas práticas sociais e políticas, de novos padrões de consumo e de um crescente setor de serviços, ditando uma série de mudanças nas práticas econômicas, políticas, culturais e espaciais (Gottdiener, 1990, p.59; Harvey, 1996, p.140; Benko, 1996).

Então, São Paulo, de locus e entreposto da indústria, passa a assumir cada vez mais a preponderância do setor de serviços. Porém, Milton Santos analisando grandes metrópoles, como São Paulo, antes de tudo, sublinha

\footnotetext{
${ }^{5}$ A dificuldade de mensurá-los deve-se à ausência de regulamentação profissional e ao fato de que boa parte dos motoboys se enquadra na informalidade.
} 
seus antagonismos por ele denominados de "modernidade incompleta" (Santos, 1990:13).

No fundo, São Paulo, no eixo das cidades mundiais, revela a mais crassa contradição da engenharia neoliberal, baseada na multiplicação do consumo em escala global, concomitantemente à proeminência dos problemas sociais de toda ordem. É neste sentido que a cidade contemporânea, baseada e organizada em função do setor de serviços, visa a garantir, prioritariamente, a aceleração da circulação e do consumo em larga escala em São Paulo. Porém, mesmo sob anuência da ação estatal quer no sentido da realização do processo de reprodução do espaço, suas infraestruturas, como também, organizando e controlando o fluxo diário de pessoas e de veículos; gerindo a velocidade, punindo os excessos, os conflitos, vigiando qualquer alteração que possa fugir de seu domínio e controle -, a cidade para - mesmo que provisoriamente -, irrita os motoristas, os passageiros, os transeuntes; inviabiliza o comércio, a distribuição, a troca, a realização do capital.

E, é neste interregno, que a figura dos motoboys torna-se imprescindível. Uma atividade profissional, que congrega na sua maioria homens, jovens com pouca qualificação profissional $^{\text {, }}$, vinculados em sua maior parte ao precário mundo do trabalho, em especial, à informalidade ${ }^{7}$, que partem - geralmente - das periferias pobres, atravessando a cidade para uma longa jornada de trabalho ${ }^{8}$. Os motoboys dotados de uma motocicleta, um veículo de duas rodas, motorizado, de pequeno porte - em relação à maior parte dos outros veículos - com certas facilidades para

\footnotetext{
${ }^{6}$ Conforme estudo publicado pela Companhia de Engenharia e Tráfego - CET - em 2002 - na cidade de São Paulo, dos 999 motociclistas entrevistados, cerca de 99,4\% eram compostos pelo sexo masculino, com predomínio de $62,9 \%$ deles na faixa etária de 20 a 29 anos. Já quanto à escolaridade, a maioria dos motoboys entrevistados havia cursado o ensino médio, 58\%; em segundo lugar, 36\%, estudaram até o ensino fundamental e $6 \%$ do total cursaram o ensino superior.

${ }^{7} \mathrm{~A}$ compreensão do processo de informalidade associado à economia e ao mundo do trabalho na sua amplitude, pode ser sintetizado, basicamente, a partir de duas categorias predominantes: os "assalariados sem registros" e os "trabalhadores por conta própria". Maria Cristina CACCIAMALI, 2000:11.

${ }^{8}$ Em entrevistas realizadas com os motoboys é comum o relato da realização de dupla jornada como forma de compor de maneira mais adequada sua remuneração.
} 


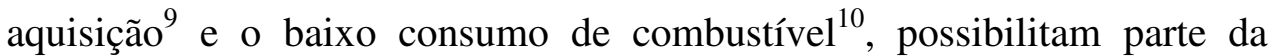
realização do consumo e dos negócios em escala ampliada em São Paulo.

Uma atividade caracterizada pela circulação rápida de um grande volume de mercadorias das lojas, dos shoppings centers, do setor varejista, de séries infindáveis de mercadorias vendidas pelo telefone ou pela internet; ou mesmo, pela realização de entregas de toda ordem vinculadas ao setor financeiro. Como também, entregas para cartórios, de exames médico-laboratoriais, sem contar as redes de alimentação e fast-food, das mais sofisticadas às mais simples, as floriculturas, joalherias e, até mesmo, objetos diversos que remetem a valores sentimentais.

Todavia para além do estabelecimento dessa nova prática socioespacial, constituída pelo ritmo alucinante e frenético impresso no dia a dia, o surgimento e a dinâmica dos motoboys aparecem como produto e necessidade da cidade de São Paulo, na transição do século XX para o XXI, revelando-se uma das profissões de maiores riscos de acidentes no trânsito na cidade de São Paulo.

Conforme dados da CET, em 2006, na capital paulista, foram registrados 35.496 acidentes com vítimas. Em 2007, esse número, mesmo que em um patamar elevado, conhece um decréscimo para 27.824 acidentes com vítimas, representando $22 \%$ a menos no período. Porém, analisando particularmente os acidentes com motociclista - mesmo que não especificado se era ou não motoboy - em 2006, ocorreram 11.286 (32\% do total) acidentes com vítimas, cerca de 30 acidentes por dia, já em 2007 esse número passou para 15.193 (55\% do total), aproximadamente 41 acidentes com vítimas por dia, determinando um aumento no período próximo a $35 \%$.

\footnotetext{
${ }^{9}$ A Honda CG Titan 150 cc custa em média cerca de $\mathrm{R} \$ 5.488$, sem contar, que a mesma pode ser adquirida através de consórcio em até 72 parcelas de $\mathrm{R} \$ 112,43$. www.honda.com.br. Acessado em 07/01/2006.

${ }^{10}$ Sobre este último, Gilvando Conceição OLIVEIRA, 2003:40 mostra que a motocicleta percorre em média 33 quilômetros com um litro de gasolina, já os chamados carros populares - os mais econômicos do ponto de vista do consumo de combustível consomem cerca de um litro a cada 13 quilômetros rodados, o que representa uma economia de mais de $100 \%$.
} 


\section{Gestão da Vida nos Circuitos da Circulação no Espaço Urbano}

A atividade profissional dos motoboys que se realiza na cidade de São Paulo, traduz-se, além de revelar parte das transformações recentes na cidade e no mundo do trabalho, passa a denotar parte de uma nova prática socioespacial, definindo certos usos, intensidade de circulação e condições de mobilidade e acessibilidade, como também possibilita compreender e discutir os mecanismos de exercícios de poder no espaço sobre esses trabalhadores urbanos.

Destarte, o espaço que compõe as normas e que as reproduz torna-se uma conditio sine qua non da realização do investimento das instâncias de poder sobre a atividade profissional dos motoboys. Pois, além do espaço e da política do espaço "exprimirem" as relações sociais, reagem também sobre elas (Lefèbvre, 1999:27; Soja, 1993:73; Gomes, 2001:25).

Então, esse espaço que se reveste de um conteúdo político ordenando a dinâmica social e hierarquizando práticas socioespaciais e instituições, possibilitando a delimitação de comportamentos e de classificação de ações sociais (Gomes, 2001:54) - é entendido pelo conceito de território. Neste ponto, C. Raffestin, explica: "O território se forma a partir do espaço, é resultado de uma ação conduzida por um ator signatário [...] em qualquer nível. Ao se apropriar de um espaço, concreta ou abstratamente [...] o ator 'territorializa' o espaço" (Raffestin, 1993:143).

Essa apropriação do espaço revela uma relação de poder na busca de certo controle a partir de um determinado território, já que "Ele (o território) é assim uma parcela de um terreno utilizada como forma de expressão e exercício do controle sobre outrem" (Gomes, 2001:12). Mas esse controle exige normas de uso do espaço, regras de acesso, de circulação, de transformação, de técnicas, etc. (Lemos, 2004:106). Isto é, uma política do/no espaço.

Tal política no espaço engendrada por relações de poder, onde o conceito de território é entendido - e apreendido - nas suas múltiplas escalas e instâncias de poder (Raffestin, 1993:16; Souza, 2001:11), faz com que o território da cidade de São Paulo comporte uma geopolítica urbana, como um objeto de disputa e busca pela afirmação de um poder que é também luta por território (Gomes, 2001:13). 
Dentre as geopolíticas urbanas impressas no território da cidade de São Paulo, a atividade profissional dos motoboys passa a ser um dos ângulos privilegiados para a compreensão do investimento e pressão das instâncias de poder na normatização desta atividade enquanto multiplicidade confusa, embaralhada, que avança em disparada nas ruas e avenidas da cidade desestabilizando e, muitas vezes, pondo em xeque todo um diagrama de leis, de normas e de regras que visam a gerir os problemas no trânsito.

Esse investimento dos mecanismos de poder sobre a ação dos motoboys é entendido como uma espécie de gestão da vida nos circuitos da circulação do espaço. Essa gestão que se dá através e por meio do espaço visa a um tratamento global e ótimo da circulação geral no trânsito urbano, como forma de controlar possíveis acidentes de trânsito, como também, de majorar e administrar a intensidade dos fluxos. Ou seja, essa gestão dá-se a partir de uma prática socioespacial definida por uma certa conduta e comportamento social, como forma de "conduzir as condutas dos outros" (Foucault, 2006).

Neste quesito, Michel Foucault nos legou importantes contribuições no que se refere à reflexão sobre as relações de poder e espaço no mundo contemporâneo. Um artigo de Gilles Deleuze (2005), intitulado Um Novo Cartógrafo mostra como a obra de Michel Foucault passa por um viés espacializante, onde os diagramas de poder entendidos como mapa das relações de força, densidade, intensidade, localização passam por pontos e estabelecem múltiplas relações. Em uma entrevista a um grupo de geógrafos franceses da revista Hérodote, M. Foucault mostrou como o espaço aparece seja como alegoria metafórica para explicitar seus conceitos, ou mesmo, como forma possível de colocar e delinear os problemas do poder e seus efeitos na sociedade moderna (Foucault, 2009:158-159) ${ }^{1 \mathrm{f}}$.

Essa política da sociedade moderna que remonta à passagem do século XVIII para o XIX aparece no contexto da gestão da população e de seus problemas como forma de normatização e regulamentação das condutas sociais, com base em uma dupla perspectiva "uma individualizante e outra totalizante" (Senellart, 1995:1), onde "gerir a população não queria dizer simplesmente gerir a massa coletiva dos

${ }^{11}$ Cf (Foucault, 2009:158-159). 
fenômenos ou geri-los somente ao nível de seus resultados globais. Gerir a população significa geri-la em profundidade, minuciosamente, no detalhe" (Foucault, 2009:291), o que elucida muito bem dois polos de uma articulação, mais do que a substituição, a transição do poder disciplinar, o que Foucault chama de "biopolítica"12 (Idem, 2006:154-155).

Essa forma de gestão da vida por meio de um poder regulamentador, intervindo para fazer viver e aumentar a expectativa de vida da população em geral, vai aparecer gerindo os problemas, seja no âmbito da segurança e ordem policial, repressiva, como também, no que concerne ao controle e normalização científica, nas suas virtualidades e probabilidades. Com efeito, a disciplina, no âmbito do biopolítica, é convertida em regulamentação. Regulamenta-se para assegurar e garantir a vida, para prevenir e evitar os descaminhos da morte, pois como diz Foucault: "Agora é sobre a vida e ao longo de todo o seu desenrolar que o poder estabelece seus pontos de fixação; a morte é o limite, o momento que lhe escapa" (Ibid., p.151).

Mas a exacerbação das racionalidades empreendidas pela gestão da vida vinculadas ao bem-estar de uma vida moldada e produzida como forma de garantir uma certa conduta, vai produzir também toda uma forma de subjetivação e intimização da vida. A produção de subjetividades, que é uma produção no minúsculo e no plural, ganha corpo e se estende pelos tentáculos da verdade, do consenso produzido. No caso brasileiro, na passagem do século XIX para o XX, o discurso da vida se valia do pobre perigoso e promíscuo, aquele trabalhador das vilas operárias, a fim de

${ }^{12}$ "Um dos polos, o primeiro a ser formado, ao que parece, centrou-se no corpo como máquina: no seu adestramento, na ampliação de suas aptidões, na extorsão de suas forças, no crescimento paralelo de sua utilidade e docilidade, na sua integração em sistemas de controle eficazes e econômicos [...] que caracterizam as disciplinas: anátomo-política do corpo humano. O segundo, que se formou um pouco mais tarde, por volta da metade do século XVIII, centrou-se no corpo-espécie, no corpo transpassado pela mecânica do ser vivo e como suporte dos processos biológicos: a proliferação, os nascimentos e a mortalidade, o nível de saúde, a duração da vida, a longevidade, com todas as condições que podem fazê-los variar; tais processos são assumidos mediante toda uma série de intervenções e controles reguladores: uma bio-política a população [...] A velha potência de morte que simbolizava o poder soberano é agora, cuidadosamente, recoberta pela administração dos corpos, pela gestão calculista da vida" (Foucault, 2006:151). 
poder permanentemente vigiá-lo e controlá-lo. A ação da polícia visava garantir um espaço higienizado e seguro.

Obviamente, esses mecanismos de poder na atualidade já foram perturbados na sua capacidade explicativa para definir certas regularidades e em gerir os problemas socioespaciais, já que a produção dos discursos de verdade e do real são constantemente reinventados, aprimorados, aplicados de maneira mais incisiva no sentido de cumprir a sua racionalidade, aquela de conduzir as condutas dos outros. Para o filósofo italiano Giorgio Agamben, a racionalidade das instâncias de poder da biopolítica que ascende na contemporaneidade, não se incumbe tanto de fazer viver, nem de fazer morrer, mas de fazer sobreviver. Ele cria sobreviventes e produz a sobrevida:

Nem a vida nem a morte, mas a produção de uma sobrevivência modulável e virtualmente infinita que constitui a prestação decisiva do biopoder de nosso tempo [...] A ambição suprema do biopoder consiste em produzir em um corpo humano a separação absoluta entre o ser vivo e o ser que fala, entre a zoè e o biós, o não-homem e do homem: a sobrevivência (Agamben, 2008: 155).

Para Agamben a sociedade contemporânea traduz-se como um verdadeiro "estado de exceção" que remete a uma relação entre a vida nua (biológica) e a vida política (qualificada), em que a vida é colocada em suspensão porque é retirada do âmbito da norma e abandonada, incluída por uma exclusão. Nesta racionalidade, o autor, valendo-se do campo de concentração nazista como metáfora, demonstra como a vida era separada entre aquelas qualificadas (passíveis de serem normalizadas) e as sobras, os sobrantes, a vida nua, descartada.

Essa sociedade contemporânea que vive às sombras do estado de exceção permanente tem sua vida jogada no centro do poder, definindo a lógica de ser do seu exercício, determinando formas de intervenções e o que deve ser gerido pelo critério da urgência em cada uma das instâncias de poder-saber: uso de drogas ilícitas, sequestro, roubo a banco, terrorismo, controle da imigração e no trânsito, sem dúvida, os motoboys.

Para Chico de Oliveira, as cidades são os lugares por excelência da exceção (2003), a gestão urbana passa, no período atual, a ser multiplicada, pois os problemas passam a se generalizar. É assim que Vera Telles e 
Hirata refletem: "nesses tempos em que a exceção se tornou a regra, a administração de suas urgências para tornar os "indivíduos governáveis" sob a égide da racionalidade triunfante do mercado". (Telles \& Hirata, 2007:186).

É dessa forma que as cidades como (campo de) concentração das multiplicidades confusas que precisam ser geridas pela ação das instâncias do poder vão investir no sentido de majorar sua condição de vida, mas desde que a cidade ponha a circular de modo cada vez mais intenso e rápido toda sorte de mercadorias, pessoas e informações.

É dessa maneira que os motoboys, enquanto multiplicidades confusas na cidade, devem ser geridos, homogeneizados. Nada deve escapar da malha fina da gestão da vida, nem a própria vida nua, matável. Esses investimentos de poder na gestão dos motoboys aparecem na forma de múltiplas estratégias, postas a intervir e disciplinar esta atividade profissional, já que além de classificar os motoboys como produtivos, rápidos e eficientes, estas estratégias visam a pô-los a circular de forma adestrada, útil e dócil, da empresa para a rua, da rua para os destinos de sua entrega (prédios, condomínios, casas, empresas, indústrias etc.), da rua para a sua casa etc.

É neste sentido onde mais do que territorializar o poder, é também fazê-lo fluir. Os motoboys, entre os fluxos e os fixos ${ }^{13}$ (Santos,2002:61; Idem, 1994:125), são geridos tanto circulando nas ruas e avenidas, quanto nos pontos de entrega das mercadorias e produtos diversos que fazem parte do cotidiano de seu trabalho para além do asfalto; são locais e situações que servirão como uma espécie de filtro seletivo e normatizador. Pois, além de inseri-los em certo comportamento e conduta, separa-os do restante, classifica-os conforme sua função, sua classe social, sua cor.

Essa articulação estratégica servirá à organização do espaço, ou melhor, para atingir a população através do espaço, visando a uma competência, uma certa utilidade, um certo comportamento e uma certa prática de sociabilidade, portanto, o espaço revela-se como:

13 "Os elementos fixos, fixados em cada lugar, permitem as ações que modificam o próprio lugar, fluxos novos ou renovados que recriam as condições ambientais $e$ as condições sociais, e redefinem cada lugar. Os fluxos são um resultado direto ou indireto das ações e atravessam ou se instalam nos fixos, modificando sua significação e o seu valor, ao mesmo tempo em que, também, se modificam" (Santos, 2002:61). 
um controle mais eficaz dos segmentos tidos como anômalos ou 'desviantes' à normatização dominante (os doentes, os loucos, os 'marginais') ou que necessitem ser adestrados para que façam cumprir os valores impostos e reconhecidos como imprescindíveis à reprodução do arranjo social (Haesbaert, 2002:84).

É esse o espaço da cidade neoliberal, uma maquinaria de normas e subjetividades. É nesta cidade que a gestão da vida aparece como uma prática e disputa de um imenso catálogo de problemas a serem geridos. É justamente nesta cidade que a rede de famintos de felicidade e satisfação marcha no vazio inédito em que as frustrações emocionais não são mais preenchidas pelo outro. Esta, organizada mais pela circulação e consumo do que pela comunicação entre as pessoas, mais pela troca do que pelo uso, mais pela morte do que pela vida. Assim o absurdo da vida é majorar a vida pela vida de outrem. É o individualismo impetrante que abole o trágico, paradoxalmente, entre a inédita apatia da sensibilização epidérmica com o mundo e a profunda indiferença ante os acidentes de trânsito envolvendo os motoboys, já banalizados e tornados regra no asfalto da grande cidade de São Paulo.

\section{Estigmas e Discriminações que os Motoboys Carregam}

A relação de socialização no trânsito da metrópole de São Paulo se posta de maneira bastante conflituosa entre os motoboys e os motoristas diversos. As polêmicas ressoam em tons apaixonados. A raiva é figadal entre as partes. A imprensa de maneira geral reproduz e ganha ibope, alavanca as vendas com a estigmatização dos motoboys. Na Revista Veja, uma matéria intitulada "Loucos pelo Perigo" começa assim: "Considerados a nova praga do asfalto por motoristas impacientes, os motoboys são cada vez mais numerosos" ${ }^{14}$, e na sequência justifica:

A convivência dos motoboys com os motoristas de carro é complicada. Também, pudera. Eles serpenteiam entre os carros, nunca avisam o que vão fazer, dão fechadas bruscas, batem nos retrovisores e nunca param para pedir desculpas.

14 Alice GRANATO. Loucos pelo Perigo. Revista Veja, 07/07/1999. 
Quando não têm espaço para passar, muitas vezes chutam a lataria dos veículos.

Em uma coluna no Jornal Folha de São Paulo ${ }^{15}$, Anna Verônica Mautner, expôs assim: "Os motoboys constituíram-se em um exército que ameaça espelhos retrovisores, pintura de porta, sobressaltando os motoristas que deveriam poder focar a sua atenção no trânsito". Mauro Chaves, do jornal $O$ Estado de São Paulo, escreveu: "uma categoria de impuníveis bestas-feras, que todos os dias aterrorizam os cidadãos, especialmente os que habitam grandes cidades, como São Paulo" 16.

É dessa forma que para Oliveira "a discriminação da categoria está ligada aos estigmas que os indivíduos e grupos atribuem aos motoboys, imputando-lhes um caráter criminoso e contraventor" (Oliveira, G., 2003:107). A respeito desta temática, a maior parte dos motoboys entrevistados afirma ter sofrido algum tipo de estigma e discriminação. $\mathrm{O}$ motoboy Carlos Eduardo reclama:

tem muita discriminação por parte da polícia,quando eles param a gente eles não param assim com respeito, sem saber quem é a gente, sem saber quem tá por baixo do capacete, trata a gente como marginal, eles não sabem que o serviço de motoboy é um serviço de 'responsa', tem que ter responsabilidade, porque a gente carrega documento importante, às vezes a gente carrega até dinheiro, tem tudo isso, os clientes confiam muito na gente.

Perguntei-lhe qual o motivo dessa perseguição e o mesmo arrisca: “ $a$ discriminação vem por parte que muitos dos motoboys é ex-presidiário, mas o pessoal não vê que eles querem uma chance na vida para se levantarem". Natércio, 41 anos, no alto de sua experiência vê a discriminação assim:

em todos os lugares, você não pode parar no farol, a pessoa olha no retrovisor vê que é motoboy e já fecha correndo. No Banco o cara fecha o sistema, você vai entrar em dia de chuva no prédio você tem que entrar pela garagem 'para não sujar o

\footnotetext{
${ }^{15}$ Anna Verônica MAUTNER. Os Motoboys e Eu. Folha de São Paulo, 05/06/2005.

${ }^{16}$ Mauro CHAVES. Impuníveis Bestas-Feras. O Estado de São Paulo, 16/06/01.
} 
ambiente'. Às vezes, você tem vontade de partir pra ignorância, você tá trabalhando, não tá brincando.

A mídia apoiada na produção de certos consensos surpreende a sociedade pelas notícias do atípico, produzindo a normatização. Todavia, os meios de comunicação não passam de uma das instâncias de poder articulada a outras tantas instâncias, no sentido de legitimar a produção de certa normalidade, certa conduta, muitas vezes, pelo seu avesso, pelo que escapa, por uma conduta não normatizada, criando uma prática da verdade e do real onde a receita é uma conduta aceitável, útil e comportada.

É assim que a operatória dessa empresa produzida cotidianamente, passa a ser revelada a partir de estratégias das instâncias de poder que perpassam do asfalto ao clima doméstico, na produção mórbida de subjetividades. É dessa forma que são criados os estigmas e as mais diversas formas de discriminação que os motoboys precisam carregar.

Não é por acaso que estas questões invertem-se a todo instante. Pois, à primeira vista, a motocicleta é associada à liberdade, no entanto para uma boa parte dos motoboys entrevistados a sensação de liberdade paira longe de sua atividade profissional. É assim que sem titubear descreve-me Antônio Dalton, 37 anos, sobre o que sente depois de uma intensa jornada de trabalho: "a sensação de liberdade é bom demais". Rosenberg de 25 anos também não hesita e responde: "Liberdade $e$ contente de ter chegado em casa”.

É por isso que "Alemão"17, diz: "ninguém em sã consciência se arriscaria em cima de uma moto, hoje, numa cidade como São Paulo”. Para ele o imperativo para o surgimento e o crescimento dessa categoria foi (e é) "a necessidade econômica e social". Natércio Silva vai um pouco além falando dos motoboys enquanto atividade profissional: "olha tem que ter coragem, o trânsito de São Paulo todo mundo conhece, em cima de duas rodas ainda é pior. É até difícil falar, para ser motoqueiro hoje além da necessidade tem que ter coragem, senão, não dá pra encarar não”.

Para o motoboy Carlos Eduardo existe certa desinformação por parte da sociedade quando o assunto é motoboy: "pessoal vê a gente passando rápido, acha que o motoqueiro tá fazendo aquilo porque é motoqueiro e é

\footnotetext{
${ }^{17}$ Ademir Martins, Presidente do Sindimoto - Sindicato dos Trabalhadores Motociclistas da Cidade de São Paulo.
} 
tudo cachorro louco. Não, a gente tem que acelerar não tem jeito...". Jeferson Silva, 22 anos, é mais direto e expõe claramente o cotidiano tenso no trânsito do espaço urbano da cidade:

todo mundo fala que motoboy é tudo louco, motoboy tá trabalhando como o cara de carro tá trabalhando, entendeu? Mas pelo fato de toda hora, todo dia em cima da moto, uma hora ou outra a gente vai acelerar um pouco mais. Todo mundo fala que a gente quebra o retrovisor de carro, mas se a gente quebrou é por que quase quebraram com a nossa vida lá atrás; é uma coisa de sobrevivência.

Mas por trás desses discursos fortes e esclarecedores dos motoboys, a maior parte dos entrevistados demonstra, mesmo aqueles com bastante experiência no trânsito, possuir bastante receio ao sair de casa pela manhã para trabalhar nesta atividade profissional. Assim, Jeferson fala-me: "todo dia que você sai de casa, você dá um beijo no moleque e não sabe se você vai voltar". Edson, 27 anos, casado e pai de família, segue a mesma linha de raciocínio: "ser motoboy é loucura. Eu tenho família, eu sou casado, eu saio aqui hoje e você não sabe se vai voltar para casa, você tem que pagar o aluguel, tem que sustentar o filho, a esposa...".

Neste sentido, ao questionarmos quais seriam os sonhos para alguns motoboys, vários deles foram enfáticos, tal como Jeferson: "Sair da rua!". Parou por um instante, e continuou: "se eu ganhasse o que eu ganho sem precisar sair pra rua, largaria na hora”. Já Nilton, explica as suas razões: "como eu fiquei desempregado, por falta de opção acabei começando a trabalhar na rua, disse que ia ser passageiro, mas já vai pra cinco anos, pra você ver como é que não tem muito emprego".

É por estas razões que parte substancial dos motoboys se considera em uma atividade profissional depreciada pela sociedade. Sobre isso Nilton expõe seus argumentos: "valoriza a gente enquanto a gente tá andando, se parar...", pensa por um instante, e continua: "todo mundo xinga os motoboys mas todo mundo quer que as pizzas cheguem rápidas $e$ quentinhas em casa, ninguém vê o nosso lado".

Enfim, mais do que distorcer visões sobre a atividade profissional dos motoboys, a mídia, entre outras instâncias de poder, reproduz consensos que além de favorecer o estigma e a discriminação dessa atividade profissional, expõe esses trabalhadores como delinquentes em 
cima de duas rodas, o que perigosamente reproduz uma antiga máxima em que a pobreza aparece como sinônimo de criminalidade. No fundo a produção desses consensos legitima uma ação do poder do Estado na tentativa de garantir a realização de um processo de normatização e regulamentaçã̃o.

\section{Normatização e Regulamentação da Atividade Profissional dos Motoboys}

É neste campo de problematização que a atividade dos motoboys passa a ser objeto e alvo do processo de regulamentação levado a cabo pelas mais diversas instâncias do poder estatal, onde mais do que se restringir aos binômios formal e informal, legal e ilegal, regular e irregular, passará a investir em um processo de normatização a fim de produzir toda uma conduta e comportamento no sentido de gerir os motoboys enquanto multiplicidade confusa no trânsito, a fim de torná-los úteis, dóceis e lucrativos.

A atividade dos motoboys, cada vez mais presente na paisagem urbana de São Paulo, vem ajudando a acirrar os ânimos já aflorados no caótico trânsito da metrópole, pois esse trabalho exercido sob os desígnios de um ritmo sempre frenético e inebriante, comumente passa por cima de normas e regras já estabelecidas.

Doravante, a prefeitura de São Paulo passa a editar uma série de leis, decretos, portarias e resoluções que regem o certame da atividade profissional dos motoboys ${ }^{18}$. Em 1999, na gestão do prefeito Celso Pitta, o motofrete - denominação oficial empregada pelo poder público para se referir à atividade dos motoboys - passaria a ser regido pelo decreto $\mathrm{n}^{\circ}$ 38.563 , de 29 de outubro de 1999, com a intenção de normatizar os trabalhadores e as empresas que atuam neste setor.

No início desse processo havia uma pressão do poder público que visava a convencer a opinião pública e os agentes envolvidos acerca das benesses que a regulamentação desses profissionais traria à sociedade. Porém, passados mais de dois anos desse decreto, conforme matéria do

\footnotetext{
${ }^{18}$ Dispõe sobre os serviços de transporte de pequenas cargas, mediante a utilização de motocicletas ou similares. Decreto nº 38.563 de 29 de outubro de 1999.
} 
Jornal Folha de São Paulo ${ }^{19}$, apenas $7 \%$ dos motoboys possuíam licença para atuar profissionalmente na cidade de São Paulo.

De um modo geral, esse fracasso inicial motivou e legitimou a ação da administração posterior, levada a cabo pela prefeita Marta Suplicy, que suspendeu os processos de regulamentação dos motoboys e a concessão de novos alvarás por supostamente discordar das regras daquele decreto. Por exemplo, entre outras regras, Carlos Zarattini, à época Secretário Municipal de Transportes, destaca a restrição àqueles que possuíam antecedentes criminais (art, 2 $2^{\circ}, \mathrm{IV}$ ), e assim disse: "Não podemos marginalizar uma pessoa que já cumpriu sua pena"20.

Contudo, no decreto $\mathrm{n}^{\circ} 41.305$, de 29 de outubro de 2001, do governo de Marta Suplicy, tendo o mesmo Carlos Zarattini à frente da pasta da Secretaria Municipal dos Transportes, verifica-se a continuidade da lei que impedia a regulamentação de motoboys com antecedentes criminais. Mais do que isso, esse novo decreto passa a ser alvo de intensas críticas, basicamente, por restringir a atividade do motoboy à pessoa jurídica na forma de empresa privada ${ }^{21}$.

Essas críticas e as intensas controvérsias podem ser corroboradas a partir da matéria do Jornal da Tarde ${ }^{22}$, em dezembro de 2001, onde o poder público justificava esta mudança como forma de facilitar a fiscalização dessa atividade profissional, assim exposto por Maria Fernanda de Moura e Souza, assessora jurídica da Secretaria de Transportes: "Fica mais fácil controlar através das empresas. E as que não forem sérias vão ter que sair do mercado"23.

$\mathrm{Na}$ prática as empresas de motofrete não foram fiscalizadas adequadamente, nem muito menos foram autuadas aquelas que operavam de maneira irregular. Dessa forma, diante das pressões sociais que aumentavam em torno dessa questão, uma matéria do Jornal da Tarde, em

\footnotetext{
${ }^{19}$ www.folha.uol.com.br, 15/06/2001. Acessado em 15/12/2005.

${ }^{20}$ Idem.

${ }^{21}$ Art. $2^{\circ}$ - Somente a pessoa jurídica credenciada na Secretaria Municipal de Transportes terá autorização para explorar o serviço de motofrete, devendo, para tanto, contratar os serviços de condutores devidamente cadastrados.

${ }^{22}$ As Novas Regras para o Trabalho dos Motoboys. Jornal da Tarde, 31/10/2001.

${ }^{23}$ Idem.
} 
outubro de 2003, chegou a relatar que os motoboys eram a segunda principal causa de irritação dos motoristas no trânsito de São Paulo ${ }^{24}$. Não tardou para ser editado um novo decreto $n^{\circ} 44.220$, de 8 de dezembro de 2003, ainda na gestão da prefeita Marta Suplicy, de modo a permitir a prestação de serviço não apenas pelas empresas privadas, mas também por autônomos, cooperativas e associações ${ }^{25}$.

Esse novo decreto regulamentar aparecia como pretexto para justificar a inexpressiva regulamentação dos motoboys através do decreto de 2001, assim descrito por Josias Lech, diretor do DTP (Departamento de Transportes Públicos) à época: "a novidade desse projeto é que os motoboys poderão se cadastrar como autônomos, o que não acontecia antes" ${ }^{, 26}$. Porém, neste decreto a novidade mesmo era na forma de operar esta atividade através de cooperativa e de associação, pois a figura do autônomo já era prevista no decreto de $1999^{27}$.

Contudo, além dessas contradições que afloravam no âmbito do poder estatal, o outro polo de disputa, os motoboys, argumentam que a regulamentação da sua atividade profissional a fim de obter o Condumoto e a Licença Motofrete ${ }^{28}$, aparecia como forma de o governo aumentar sua arrecadação sobre a categoria ${ }^{29}$. Assim explicita incisivamente o motoboy

${ }^{24}$ Com o título "Trânsito e motoboys, eis o que irrita os paulistanos", o Jornal da Tarde de 27 de outubro de 2003.

${ }^{25}$ Art. $2^{\circ}$. O serviço poderá ser prestado por condutor autônomo ou por pessoa jurídica, constituída sob a forma de empresa comercial, associação ou cooperativa, que explore esse serviço por meio de frota própria ou não, mediante prévia autorização e licença, nas condições estabelecidas neste decreto e em demais atos normativos.

${ }^{26} \mathrm{http} / / / \mathrm{www}$.folha.com.br/folha/cotidiano/ult95u85896.shtml. Acessado em 02/08/05.

${ }^{27}$ Art. $1^{\circ} \mathrm{O}$ serviço de transporte de cargas, previsto na Lei n. 7.329 , de 11 de julho de 1969 , poderá ser prestado por condutor autônomo, devidamente habilitado, ou por pessoa jurídica que explore esse serviço através de frota própria ou não, mediante a utilização de motocicletas ou similares.

28 O condumoto é um documento concedido ao condutor que cumpre (ele e sua motocicleta) uma série de exigências estabelecidas e tem um prazo de validade de 5 (cinco) anos $\left(\operatorname{art.} 9^{\circ}\right)$. A Licença de Motofrete é o documento pessoal e intransferível pelo qual é autorizada a utilização de motocicleta para a prestação do serviço a que se refere este decreto. Decreto $\mathrm{n}^{\circ}$ 44.220, de 8 de dezembro de 2003.

29 Para o motoboy se regulamentar conforme o decreto $\mathrm{n}^{\circ} 44.220$, de 8 de dezembro de 2003, o valor cobrado - incluindo o curso obrigatório - era em média cerca de R\$170. 
Nilton: "Na verdade eles querem arrecadar dinheiro em cima de uma classe que eles sabem que é grande. Sabendo que essa lei vai arrecadar um dinheiro, e é uma coisa cara que você praticamente nem vai usar".

Mais do que isto, paulatinamente os motoboys, mesmo ainda sob uma organização cadente, tornar-se-iam alvos dos políticos em busca de votos para a eleição municipal, em 2004, em São Paulo. Em uma matéria jornalística que tỉnha a seguinte chamativa "Contra Marta, 'exército' de 200 mil motoboys vira alvo de Maluf e Serra", a jornalista Cátia Seabra da Folha de São Paulo ${ }^{30}$ escreveu assim sobre o tema:

Com a distribuição de camisetas e a promessa da extinção de taxa para regularização da categoria, o candidato do PP à Prefeitura de São Paulo, Paulo Maluf, dá a largada a uma corrida pela conquista de um exército estimado em até 200 mil eleitores: o dos motoboys [...] Mas, nessa disputa, o tucano José Serra não fica atrás. Ainda nesta semana, Serra deverá receber a manifestação de apoio de dois grupos até mais representativos: o Sindmmoto (Sindicato de Trabalhadores Motociclistas do Município de São Paulo) e a Abram (Associação Brasileira de Motociclistas).

Findo o pleito eleitoral, José Serra é eleito e empossado prefeito de São Paulo e tão logo muda seu discurso. Já que a promessa de campanha feita aos motoboys, entre outras, a de acabar com as taxas para regulamentar essa atividade não foi cumprida. Pois o que ocorreu foi a diminuição relativa dos custos de regulamentação da atividade dos motoboys para cerca de $\mathrm{R} \$ 100,00^{31}$ - incluindo o curso obrigatório. Contudo, levando em consideração uma série de novas exigências, tais

http://www6.prefeitura.sp.gov.br/portal/acidade/notícias. Acessado em 11/08/2005. No jornal Folha de São Paulo, os motoboys argumentavam sobre a inviabilidade dos custos: os motoqueiros argumentam que estão gastando uma média de $R \$ 280$ para obter toda a documentação necessária para a profissão, somados os valores do cadastro, dos cursos e da documentação da moto na Prefeitura de São Paulo. O cálculo não inclui o custo do baú exigido - que varia de $R \$ 55$ a $R \$ 70$. Motoboy sem cadastro já é multado em SP. Jornal Folha de São Paulo, 30/07/04.

${ }^{30}$ Cátia SEABRA. Contra Marta, 'exército' de 200 mil motoboys vira alvo de Malufe Serra. Folha de São Paulo, 8/8/2004

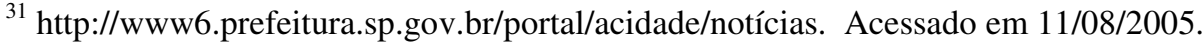


como aquelas determinadas pela portaria $\mathrm{n}^{\circ}$ 090/05 de 20 de outubro de 2005 , que estabeleceu normas complementares para o serviço de motofrete, que obrigava os motoboys a comprar o chamado kit de segurança, que incluía: antena (para evitar ferimentos provocados por linhas de pipas com cerol); mata-cachorro (equipamento de proteção dos membros inferiores, instalados nas laterais dianteiras das motocicletas); capacete com identificação (nome, tipo sangüíneo do condutor e faixas reflexivas); bota; colete especial (com faixas reflexivas) e baú (para o transporte de cargas), totalizou-se um custo aproximado de $\mathrm{R} \$ 290,00$.

Fato é que este decreto do prefeito José Serra apresentou poucas mudanças à baila no tocante à regulamentação dos motoboys. No fundo, o Decreto de $\mathrm{n}^{\mathrm{o}} 46.168$, de 11 de agosto de 2005, ainda marginalizava os motoboys com antecedentes criminais ${ }^{32}$ e, mais do que isso, o texto do decreto acerca do curso de educação no trânsito como item necessário à regulamentação da categoria, mesmo que não seja uma novidade em relação aos decretos anteriores, especialmente neste, percebia-se uma carga preconceituosa e discriminatória, assim descrito em seu artigo $9^{\circ}$, parágrafo $\S 1^{\mathrm{o}}$ :

O Curso Especial de Treinamento destina-se a propiciar aos condutores o perfeito atendimento e observância das regras de trânsito e das obrigações a que se refere o presente decreto, incluindo conhecimentos sobre prevenção de acidentes, socorros de emergência, princípios de relações humanas, de cortesia e higiene, entre outros julgados convenientes para sua formação profissional.

Já em 2006, diante da preocupação do prefeito José Serra em alçar sua candidatura ao governo do estado de São Paulo, não demorou muito para este renunciar à prefeitura e, em 31 de março de 2006, o vice prefeito Gilberto Kassab, assumiu a administração da cidade de São Paulo. Consciente da inépcia operante em fiscalizar e enquadrar a maior parte dos

${ }^{32}$ Decreto de $n^{\circ} 46.168$, de 11 de agosto de 2005, Art. 9º, inciso III: "Certidões de antecedentes criminais, expedida pelo Cartório do Distribuidor Criminal e pela Vara das Execuções Criminais da Comarca da Capital, bem como pela Justiça Federal, com as devidas certidões de objeto e pé e/ou execução penal explicativa quando houver anotações". 
motoboys e empresas do setor consideradas irregulares ${ }^{33}$, o poder público paulatinamente passa a buscar algumas alternativas, visando de certo modo a dividir o ônus do problema com a sociedade em geral. Assim foi criado o Selo Trânsito Seguro ${ }^{34}$.

Todavia, esta espécie de selo de qualidade respaldada pelo poder público se deparava com o fato de que a sociedade que usa o serviço dos motoboys continuava, em grande medida, baseando-se pelo binômio preçopressa. Assim, esta atividade operada por empresas regularizadas junto à Prefeitura e, algumas delas, portadoras do selo trânsito seguro aparece para os clientes tomadores de serviço não como empresas responsáveis socialmente, mas antes de tudo, como empresas careiras. O empresário do setor, Ronaldo Brito, da BME, um dos idealizadores desse selo, contou-nos a este respeito:

Posso dizer que com o selo trânsito seguro fui procurado por muitas empresas, querendo contratar nosso serviço. Só que tinha um problema na hora que eu ia apresentar os preços, muitas empresas que não registravam seus funcionários caíram no mesmo problema: eu cobrava 30 (reais) e a deles 18 (reais).

É neste cenário caótico que a Prefeitura de São Paulo, através da CET, decide criar corredores preferenciais e exclusivos para motocicletas com o objetivo de mitigar os acidentes, cada vez mais comuns com este tipo de veículo. Como teste inicial desta empreitada a CET lança em 24 de julho de 2006 uma faixa preferencial denominada de faixa cidadã, compreendendo as Avenidas Eusébio Matoso e Rebouças e a Rua da Consolação. Todavia, por ser uma faixa preferencial, além de não impedir a circulação de outros veículos, por si só não criou o cidadão paulistano como esperado. No máximo serviu para expor o problema à sociedade

33 "Apenas $10 \%$ dos cerca de 200 mil motoboys da capital se adequaram às novas regras do serviço de motofrete [...] Das 2.500 em atividade na capital, só 500 estão regularizadas". Jornal O Estado de S. Paulo, 1 de dezembro de 2006.

34 "O Selo é uma logomarca oficial concedida pela CET que visa incentivar práticas de segurança no cotidiano das empresas que lidam com motociclistas profissionais, prestando serviços de motofrete ou administrando a frota de motociclistas na realização de sua atividade econômica no município de São Paulo". http://www.cetsp.com.br. Acessado em 20/07/2009. 
civil. Doravante, a CET decide então criar uma faixa exclusiva para motos na Av. Sumaré, no dia 18 de setembro de 2006. Contudo, como esta avenida tem uma baixa circulação de veículos serviu (e serve) muito mais como um teste do que necessariamente como forma de evitar acidentes envolvendo motocicletas.

Assim, diante das mais diversas controvérsias e interesses, em 22 de janeiro de 2008 a CET decide realizar um teste de faixas exclusivas para as motocicletas na Av. 23 de Maio, que concentra um grande fluxo de motocicletas ${ }^{35}$. Entretanto, devido a falhas técnicas de concepção acabou gerando sérios transtornos ao trânsito e polêmicas entre os seus diversos usuários $^{36}$. Fato é que o espaço como um elemento cada vez mais raro no trânsito de São Paulo é alvo e interesse dos mais diversos matizes da sociedade $^{37}$.

Porém, em concomitância a essas alternativas que não se viabilizaram - o selo trânsito seguro e a criação de faixas preferenciais e exclusivas para motocicletas - o então prefeito em exercício, Gilberto Kassab, sancionou a Lei $\mathrm{N}^{\circ} 14.491$, de 27 de julho de 2007, quase sem alterações em relação às exigências aos motoboys e às empresas impressas no decreto anterior publicado no governo de José Serra.

No dia 15 de fevereiro de 2008 estava marcada a data para o cadastramento da Lei $\mathrm{n}^{\circ} 14.491$, e como novidade o motoboy teria a possibilidade de fazer o Curso Especial e Treinamento (art.10 ${ }^{\circ}$, IV) de forma gratuita e com horários flexíveis. Porém, uma matéria do Jornal Diário do Comércio", dizia "Na primeira turma do curso, 140 pessoas se

35 Entre as Avenidas Vinte e Três de Maio e Rubem Berta chegam a circular 6.161 motocicletas por dia. CET. Desempenho do Sistema Viário. Monitoração da Fluidez, vol. 2006.

${ }^{36}$ Do G1 SP. Reprovada, faixa exclusiva na Av. 23 de Maio termina nesta quarta. http://g1.globo.com/Noticias/SaoPaulo. Acessado em 25/01/2008.

${ }^{37}$ Em 02 de junho de 2010, a Prefeitura de São Paulo inaugurou uma motofaixa de 3,5 quilômetros de extensão, com o trajeto entre a Avenida Lins de Vasconcelos e a Praça João Mendes, seguindo pela Rua Vergueiro e a Avenida Liberdade, com a intenção de proibir a circulação na Av. 23 de maio. http://g1.globo.com/brasil/noticia/2010/06/em-spmotofaixa-da-vergueiro-comeca-a-funcionar-hoje.html. acessado em 07/06/2010.

${ }^{38}$ Maristela Orlowski. Secretaria promove primeiro curso de formação de motoboys. Jornal Diário do Comércio, 17 de março de 2008. 
inscreveram, mas pouco mais da metade compareceu às aulas no primeiro dia". Para se ter uma dimensão deste fato, de um universo aproximado de 200 mil motoboys na cidade de São Paulo, em outubro de 2008, apenas $3.258^{39}$ portavam seu condumoto (em validade). O motoboy Carlão, 42 anos, apesar de concordar com o processo de regulamentação e ter tirado o condumoto, reclama que nenhum órgão competente o requisitou:

\begin{abstract}
eu acho válido pra caramba, tanto que eu sou cadastrado, você pegou uma pessoa cadastrada? Vou até te mostrar o meu condumoto [...] eu tirei essa carteira aqui já fez um ano e pouco só que até hoje não me pediram essa carteira pra nada, é um monte de documento, você faz uma semana de escolinha, é um monte de documento que você faz, que você tira em fórum, no DETRAN, no próprio DTP, no CET que você faz a escolinha, só que até agora não vigorou, eles só falam, falam, mas...
\end{abstract}

Perguntei a Roberto Alegretti, Diretor do DTP, porque não conseguiam regularizar e fiscalizar esta atividade. E ele respondeu:

a lei do motofrete é recente e nós estamos fazendo um esforço para trazer todo esse grupo que a gente nem sabe exatamente quem é e o número exato de componentes desse grupo para trazê-los pra formalidade. Eles são totalmente informais [...] Mas você não consegue enquadrar todo mundo porque é uma categoria diferente, não é a mesma coisa que o perueiro, por exemplo. Você pode pensar: 'não, mas os perueiros foram enquadrados'. Mas é outra coisa fazer uma linha, a fiscalização era mais fácil de ser feita. Os motoboys não. Você tem uma empresa no extremo leste da cidade que tem dois, três motoboys. Como é que você alcança essas pessoas pra fiscalização? Amanhã dois deles saem para arrumar outro emprego menos arriscado e aí dois outros tiram a carta e vão lá para serem os motoboys que vão fazer o trabalho pra essa empresa.

${ }^{39}$ Essas informações foram concedidas pelo Cel. Roberto Tosta, Assessor do DTP. 
De outro modo Heloísa Martins, Gestora de Trânsito da CET, elucida a relação entre a omissão do poder público e a dinâmica da atividade profissional dos motoboys:

A maioria dos motociclistas da cidade não são motofretistas,
só um quarto dos motociclistas que são motofretista, no
entanto é um grupo mais visado e estigmatizado pela mídia e
então a falta de educação e a agressividade não é privilégio
dos motofretistas e desenvolveu uma consciência que é
proprietário da via que resta entre os veículos e exige que se
respeite isso, uma espécie de terra de ninguém. Isso porque o
poder público se omitiu escandalosamente, não fiscalizou, se
omitiu, não tomou nenhuma iniciativa, a gente chega hoje
depois de 10 anos do boom de crescimento das motocicletas
em uma situação quase fora de controle.

Destarte, o poder público na ânsia de varrer os motoboys das ruas e avenidas de São Paulo como seres indesejáveis, insiste em tratar essa questão estritamente pelo viés jurídico, quando no fundo a questão é, antes de tudo, social $^{40}$.

Desse modo, a regulamentação como forma de racionalidade sobre a atividade dos motoboys, mais do que tirá-los de uma condição de marginalidade, insere-os em um circuito renovado e circulante de informalidades, ilegalidades e irregularidades. E, contraditoriamente, neste choque com as instâncias de poder a análise da atividade profissional dos motoboys, mais que permitir uma reflexão acerca da gestão da circulação no espaço urbano que se viabiliza, no limite, em detrimento da vida de outrem, possibilita entender as formas de resistências desses trabalhadores nas ruas e avenidas de São Paulo.

\footnotetext{
${ }^{40}$ Deste mesmo modo, em âmbito nacional, a lei federal $n^{\circ} 12.009$, de 29 de julho de 2009 e a resolução $\mathrm{n}^{\circ} 350$, de 14 de julho de 2010 , apesar de dispositivos que visam a mitigar a condição social desses trabalhadores urbanos, principalmente, das grandes cidades brasileiras, não representam nenhuma novidade que vise de fato à dignidade humana dos motoboys.
} 


\title{
Espaço de Resistência: Cotidiano e Cultura dos Motoboys
}

Os motoboys, contraditoriamente, dotados do poder da fluidez, agilizam as entregas, põem o trânsito a fluir e, ademais, expostos aos riscos de acidentes de trânsito, caem, interditam o tráfego. Daí em diante, tornamse alvos e objetos das instâncias de poder como forma de conduzi-los, manipulá-los e, no limite, eliminá-los das ruas e avenidas. Mas justamente neste choque com as instâncias de poder revela-se um novo campo de lutas e resistências sob a pecha da nova etapa do capitalismo, centrada em torno do trabalho precário e do espaço.

Neste novo diagrama de relações de poder para além do chão da fábrica, a cidade torna-se o espaço das resistências. O cotidiano neste esteio traduz-se como um campo de lutas táticas, que vistas pelo ângulo da atividade profissional dos motoboys, são travadas palmo a palmo no asfalto que anuncia novas formas de identidades (forjadas ou não) e de organização do trabalho frente ao capital, pois como nos ensina Lefèbvre:

\begin{abstract}
cotidiano aponta-nos para o fato de que o social não é redutível ao econômico (relações de produção e de propriedade) refere-se às relações entre os indivíduos e o grupo e, deste com a sociedade, manifestando-se como lugar dos conflitos entre o racional e o irracional, entre o efêmero e o que persiste [...] (onde) se formulam os problemas da reprodução no sentido mais amplo, isto é, a forma como é produzida a existência social dos seres humanos. (Lefèbvre, 1991:65)
\end{abstract}

Para Michel de Certeau, são as práticas cotidianas que rompem com o espaço disciplinar, o lugar (Certeau, 1994), pois "é no lugar vivenciado onde todos os confrontos se explicitam e se individualizam; onde o poder se exercita" (Neves, 1994:277). Para Iná de Castro a definição e o controle dos limites do cotidiano das sociedades passam pelo território como materialidade e arena dos interesses e das disputas dos atores sociais e pelo poder como um exercício resultante de relações assimétricas que se organizam no interespaço do mundo social (Castro, 2005: 52). Esse poder problematizado por M. Foucault "é menos uma propriedade que uma estratégia, e seus efeitos não são atribuídos a uma apropriação, 'mas a disposições, a manobras, táticas, técnicas, funcionamentos"' (Deleuze, 2005:41), portanto, somente existindo em ato, uma "ação sobre ações" 
(Foucault, 1995:243). Neste sentido, disperso, relacional, micro e cotidiano o "poder está em toda parte; não porque englobe tudo e sim porque provém de todos os lugares" (Idem, 2006:103).

É neste universo que os motoboys reunidos sob o plano do vivido, na sua relação com o outro (o motorista de carro, o pedestre, os agentes fiscalizadores etc) e com o mundo (sistema dominante, ideologia, valores sociais etc), praticam e raciocinam globalmente a sua condição de vida, entremeada na totalidade do presente (o trabalho, a vida privada, os lazeres, cultura). Assim, como produto direto da reprodução social, os motoboys são, também, resultado de lutas e formas de resistências às relações de poder, pois "onde há poder, há resistência" (Ibid., p.105).

Então, as racionalidades de poder que se movem e se exercem sobre a atividade profissional dos motoboys podem ser flagradas no contato, no choque com o poder. Os motoboys como uma espécie de infames do asfalto, vistos e ouvidos, surpreendem pelo atípico e pelo disparate "entre a ordem minúscula dos problemas levantados e a enormidade do poder aplicado" (Foucault, 2003: 218); como objetos desviantes do trânsito, agilizam e atrapalham, vão de necessários a descartáveis, de controláveis a insurgentes, põem na ordem do dia o nobre desafio de ultrapassar a linha ${ }^{41}$, pressupõem uma maneira de iluminar a vida a partir do outro, um olhar singular sobre a vida, ou mesmo uma maneira de escapar da vida gerida, para a vida vivida.

A sociedade, no geral engendrada pelas racionalidades do mundo da mercadoria, que povoam as práticas socioespaciais, suspende o compromisso com o outro, e ao suspendê-lo, tem sua identidade afirmada pelo outro, como um problema do poder. É neste sentido que para M. Castells "a construção da identidade sempre ocorre em um contexto marcado por relações de poder" (Castells, 2000:24).

Neste esteio os motoboys perpassados de maneira constante e diferencial de identidade se inventam na sua relação com os outros

41 No texto A Vida dos Homens Infames, Foucault proclama a força de relatos de pequenos crimes, delitos e desvios de toda ordem que constam em registros oficiais no século XVII no seu contato com o poder: "o ponto mais intenso das vidas, aquele em que se concentra sua energia, é bem ali onde elas se chocam com o poder, se debatem com ele, tentam utilizar suas forças ou escapar de suas armadilhas" (Foucault, 2003, p. 208). 
usuários do trânsito urbano ou, de outro modo, na sua relação com a sociedade em geral, seja na sua convivência, na extração do que há de comum, no conflito e na intolerância entre si.

E é justamente na cidade de São Paulo onde as novas práticas socioespaciais se afirmam e são difundidas pelas racionalidades de mercado, baseadas nas exigências da fluidez e na ordem do consumo, que as relações socioespaciais presididas pela forma-mercadoria são elevadas ao seu limite mais extremo e selvagem. Em uma sociedade imbuída nessa relação alienante, letargicamente, o homem se coisifica e põe o capital a se multiplicar. Seu movimento, tornado dádiva e estorvo, dilui-se no cotidiano em puro estado de emergência.

Mas a superação dessa condição, a elaboração das "contraracionalidades" (Santos, 2002:309), traduz na verdade, a realização de um espaço da emoção, da força do cotidiano e da esperança libertadora, o lugar dos homens e para os homens, a partir do espaço da cultura que dá voz ao cidadão, é a revanche sobre o espaço econômico:

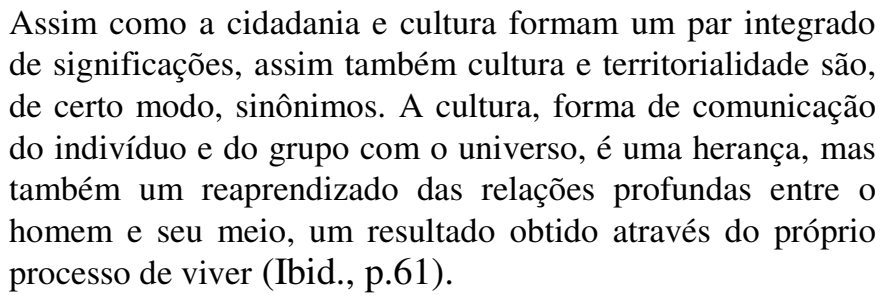

Os motoboys que surgem justamente no contexto das crises sindicais e de identidade da classe trabalhadora (Antunes, 2003:70) mais do que suscitar os pontos de resistência, revelam-se como focos incandescentes de contra-racionalidades na paisagem cinzenta da metrópole. Nestes termos, os motoboys lançaram-se nas ruas e avenidas de São Paulo no início de 2008 a fim de recusarem as novas imposições do poder regulador e normatizador. A primeira grande mobilização de motoboys deu-se no dia 11 de janeiro de 2008, organizada por Ernane Pastore, Presidente da AMM, que contou com a participação de 2500 motoboys. Estes, protestando contra o aumento do seguro obrigatório (DPVAT) para licenciar a motocicleta - que subiu de $\mathrm{R} \$ 183,84$ para $\mathrm{R} \$ 254,16$ - e contra as resoluções 203 e 219 do Conselho Nacional do Trânsito (Contran) que estabeleciam, respectivamente, a disciplinarização do uso do capacete e de 
equipamento de segurança - partiram do Pátio do Colégio no centro, passando pela sede da Prefeitura, pela Avenida Paulista e foram até a Marginal Pinheiros ${ }^{42}$.

Outra manifestação realizada em 18 de janeiro de 2008, organizada por Gilberto dos Santos, o Gil, presidente do SindimotoSP, deu-se devido à intenção da Prefeitura de São Paulo de proibir o uso da garupa da motocicleta para passageiro e, também, de proibir a circulação de motocicletas nas vias expressas das Marginais Pinheiros e Tietê a partir do dia 11 de fevereiro de $2008^{43}$.

É assim que a categoria dos motoboys, guiada por lideranças emergentes dentro de um espaço de rivalidade entre sindicatos e associações, aponta e atualiza sua força política no contexto da precarização no mundo do trabalho que se dá no espaço, contraditoriamente, como arma da fluidez e da interdição. É desse modo que os motoboys, usualmente donos dos corredores, tomam o asfalto e colocam a centralidade do trabalho e do espaço como trunfo político frente à ação das instâncias de poder - não é por acaso que no ano de eleição a Prefeitura de 2008 que o prefeito Gilberto Kassab decide recuar de suas proposições.

É neste sentido que mais do que o fim do embate da relação capitaltrabalho, os motoboys - muitas vezes, na sua condição de trabalho precário - ascendem no asfalto da metrópole e lutam tendo o espaço como locus da resistência. Não por acaso H. Lefèbvre advertia: "nenhuma revolução social pode ter êxito sem ser, ao mesmo tempo, uma revolução consciente espacial" (Lefèbvre, 1974 apud Soja, 1993: 116).

42 REBELLO, Aiuri. Protesto de motoboys fecha marginal e pára o trânsito. Jornal Diário de São Paulo, 12/01/08.

${ }^{43}$ Borges, Danielle. Motoboys protestam na capital. Jornal Diário de São Paulo, 19/01/2008. 


\section{MOTOBOYS EM SÃO PAULO: GESTÃO DA VIDA NOS CIRCUITOS DA CIRCULAÇÃO NO ESPAÇO}

Resumo: A atividade profissional dos motoboys traduz parte das transformações socioespaciais na cidade de São Paulo na transição do século XX para o XXI, encarnando dois polos de um mesmo problema a partir da nova condição da cidade e do mundo do trabalho, traduzido como um ângulo privilegiado de análise dos mecanismos de exercício das instâncias de poder na gestão da vida nos circuitos da circulação no espaço urbano paulistano.

Palavras-chave: Cidade; Espaço; Gestão; Trabalho; Motoboys

\section{MOTOBOYS IN SAO PAULO: MANAGEMENT OF LIFE IN CIRCUITS OF CIRCULATION IN THE SPACE}

Abstract: The professional activity of motoboys translate part of sociospatial transformations in the city of São Paulo the transition from the twentieth to the twenty-first century, embody two poles of the same problem from the new condition of the city and the world of work, translated as a privileged angle of analysis of the mechanisms for the exercise of instances of power in the management of life in the circuits of movement in the urban Sao Paulo.

Keywords: City; Space; Management, Work, Motoboys

\section{BIBLIOGRAFIA}

AGAMBEN, Giorgio. (2008) O que resta de Auschwitz: o arquivo e a testemunha: homo sacer III. Boitempo. São Paulo .

ALVES, Giovanni.(2000) O Novo (e Precário) Mundo do Trabalho: reestruturação produtiva e crise do sindicalismo. FAPESP/ Boitempo Editorial. São Paulo.

ANTUNES, Ricardo.(1995) Adeus ao Trabalho? Ensaio sobre as metamorfoses e a centralidade do mundo do trabalho. Cortez / Unicamp. São Paulo. 
BENKO, Georges. (1996) Economia, Espaço e Globalização. Hucitec. São Paulo.

CACCIAMALI, M.C. (2000) Globalização e Processo de Informalidade. Economia e Sociedade, IE, UNICAMP, São Paulo, n.14, p. 153-175, jul.2000.

CASTELLS, Manuel.(2000) Sociedade em Rede. O poder da identidade. Paz e Terra. São Paulo.

COMPANHIA DE ENGENHARIA E TRÁFEGO - CET. (1995 /2001) Motocicletas - Evolução do número em circulação .

. (2001) Evolução do Número em Circulação, Acidentes e Vítimas. Monitoração da Segurança.

. São Paulo Reduz os Acidentes de Trânsito.

Ações de segurança.

Município de São Paulo, 2005.

(2005) Acidentes de Trânsito Fatais no . (2005) Pesquisa Qualitativa Motociclista. Club de Pesquisa Opinião \& Mercado, 2005.

Sumário de Dados, 2006.

. (2006) Locais mais Perigosos de São Paulo.

Monitoração da Fluidez, vol. 2006.

(2006) Desempenho do Sistema Viário. . (2006) Mortes em Acidentes de Trânsito no Município de São Paulo.

. (2007) Mortes no trânsito em 2007 - resumo mensal-dezembro. Gerência de Segurança no Trânsito.

CARLOS, Ana Fani. (2001) Espaço-Tempo na Cidade. Ed. Contexto. São Paulo.

CASTRO, Iná Elias de.(2005) Geografia e Política: Território, Escalas de Ação e Instituições. Bertrand Brasil. Rio de Janeiro.

CLAVAL, Paul.(1979) Espaço e Poder. Zahar. Rio de Janeiro.

CERTEAU. Michel de. (1994) A Invenção do Cotidiano: artes de fazer. Petropólis. Vozes.

DELEUZE, Gilles. (2005) Foucault. Edições 70. Lisboa. 
DINIZ, Eugênio Pacelli Hatem. (2003) Entre as Exigências de tempo e os Constrangimentos do Espaço: As condições acidentogênicas $e$ as estratégias de regulamentação dos motociclistas profissionais. Dissertação (Mestrado em Engenharia da Produção) UFMG. Minas Gerais.

FOUCAULT, Michel. (1987) Vigiar E Punir: História da violência nas prisões. Vozes. Petrópolis.

.( 1978 / 2003) A Vida dos Homens Infames. In: Ditos e Escritos IV. Estratégia, Poder-Saber. Forense Universitária. Rio de Janeiro.

Graal. São Paulo.

(2006) História da sexualidade: a vontade de saber.

Janeiro.

(1979 / 2009) Microfísica do Poder. Graal. Rio de

(1995) Sujeito e poder. In: DREYFUS, Hubert e RABINOW, Paul. Michel Foucault, uma trajetória filosófica: para além do estruturalismo e da hermenêutica. Forense Universitária. Rio de Janeiro.

GOTTDIENER, Mark. (1990) A Teoria da Crise e a Reestruturação sócioespacial: o caso dos EUA. In: PRETECEILLE, Edmund $\mathrm{e}$ VALLADARES, Lícia (Orgs.). A Reestruturação Urbana. Nobel. São Paulo .

GOMES, Paulo César da Costa. (2002) A Condição Urbana: ensaios de geopolítica da cidade. Bertrand Brasil. Rio de Janeiro.

HAESBAERT, Rogério.(2002\} Territórios alternativos. Editora da Universidade Federal Fluminense. Niterói.

HARVEY, David. (1992) A Condição Pós-Moderna - Uma Pesquisa sobre as Origens da Mudança Cultural. Ed. Loyola. São Paulo.

INSTITUTO DE PESQUISA ECONÔMICA APLICADA - IPEA. (2003) Impactos sociais e econômicos dos acidentes de trânsito nas aglomerações urbanas brasileiras. Brasília.

LACOSTE, Yves. (1985) Geografia: isso serve, em primeiro lugar, para fazer a guerra. Ed. Papirus. Campinas.

LEFÈBVRE, Henri. (1976) Espacio y Política: el derecho a la ciudad. Península. Barcelona. 
São Paulo.

(1991) A Vida Cotidiana no Mundo Moderno. Ática.

LEMOS, Amália Inês Geraiges de. (2004) São Paulo: A Metrópole Financeira da América do Sul. In: Carlos, Ana Fani \& Oliveira, Ariovaldo Umbelino (Orgs). Geografias de São Paulo: A Metrópole do Século XXI. Contexto. São Paulo.

MARTINS, Renato; DOMBROWSKI, Osmir et al. (2000) Mapa do Trabalho Informal na Cidade de São Paulo. Ed. Fundação Perseu Abramo. São Paulo.

MARX, Karl.(1998)O Capital - Crítica da Economia Política. Livro Primeiro. O processo de produção do capital. Ed. Nova Cultural,São Paulo.

$$
\text { (1970) O Capital - Crítica da Economia Política. Livro }
$$

Segundo. $O$ processo de circulação do capital. Vol.III. Civilização Brasileira, Rio de Janeiro, 1970.

OLIVEIRA, Francisco. (2003) Crítica à Razão Dualista: O Ornitorrinco. São Paulo. Ed. Boitempo.

OLIVEIRA, Gilvando Conceição. (2003) Trabalho, Vitimização $e$ criminalização no cotidiano de motoboy de Salvador. Dissertação (Mestrado em Saúde Pública) UFBA. Salvador.

RAFFESTIN, Claude. (1993) Por uma Geografia do Poder. Ática. São Paulo.

SANTOS, Milton. (1990) Metrópole Corporativa Fragmentada: o caso de São Paulo. Secretaria de Estado da Cultura/Nobel. São Paulo.

. (1994) Tempo. Globalização e Meio Técnico-Científico Informacional: Ed. Hucitec. São Paulo. 1994.

(2002)A Natureza do Espaço - Técnica e tempo, razão e emoção. Edusp. São Paulo.

SENELLART, Michel. (1995) A Crítica da Razão Governamental em Michel Foucault. Tempo Social - Revista de Sociologia da USP 7, São Paulo, no 7(1-2), p.1-14, out. de 1995.

SILVA, Ricardo Barbosa. (2009) Os Motoboys no Globo da Morte: Circulação no Espaço e Trabalho Precário na Cidade de São Paulo. Dissertação (Mestrado em Geografia Humana) USP. São Paulo, . 
SOJA, Edward W. Geografias Pós-modernas. (1993) A reafirmação do espaço na teoria social crítica. Jorge Zahar Editor. Rio de Janeiro.

SOUZA, Marcelo José Lopes de.(2001) O território: sobre espaço e poder. Autonomia e desenvolvimento. In: CASTRO, I. E. de; GOMES, P. C. da C.; CORRÊA, R. L. (Orgs.). Geografia: conceitos e temas. Bertrand Brasil. Rio de Janeiro, p. 77-116. 